WMJ (Warmadewa Medical Journal), Vol. 5 No. 2 2020, Hal. 76-84

\title{
Differences in Sociodemographic Characteristics of Schizophrenia Patients between Rural and Urban Areas in Badung Regency
}

\author{
Ni Made Setiawati ${ }^{1}$, Luh Putu Suaryani ${ }^{2}$ \\ ${ }^{1,2}$ Udayana University, Master of Public Health, Denpasar, Bali \\ Email ${ }^{1}$ :madetia97@gmail.com
}

\begin{abstract}
Several studies have found differences in the incidence of schizophrenia in rural and urban areas. Most of the studies found that schizophrenia incidence was higher in urban areas. The purpose of this study was to determine differences in sociodemographic characteristics of schizophrenic patients according to rural or urban conditions in their homes. An observational, cross-sectional analytic, study conducted. The sample in this study were 503 people who had been diagnosed with schizophrenia recorded at community health centres in Badung Regency until October 2019. Sociodemographic data of patients were observed and then grouped according to the residence of rural or urban patients. Chi-square test with a significant value of $\mathrm{P}<0.005$ used to analyze the result. The proportion of schizophrenia is higher in urban than in rural areas $(61.1 \%: 38.9 \%)$. There are differences in the incidence of men and women in villages and cities $(p=0.011)$, differences in rural and educational events low whereas in urban areas on the contrary $(\mathrm{P}<0.0001)$. More schizophrenic patients do not work and live in cities than in villages $(\mathrm{p}=0.002)$ and that people who are not married and live in cities suffer more schizophrenia $(p=0.014)$, only the age group variable was no difference $(p=0.14)$. The incidence of schizophrenia is higher in urban areas with differences in characteristics found in variables of gender, education level, employment status and marital status. Thus, can be an input to the health department and staff so that psychological education and screening are more directed at urban communities.
\end{abstract}

Keywords: Schizophrenia, rural, urban sociodemography

\section{Abstrak \\ [Perbedaan Karakteristik Sosiodemografi Pasien Skizofrenia antara Perdesaan dan Perkotaan di Kabupaten Badung]}

Beberapa penelitian menemukan adanya perbedaan kejadian skizofrenia di pedesaan dan perkotaan, sebagian besar hasil penelitian menemukan kejadian skizofrenia lebih tinggi di daerah perkotaan. Tujuan dari penelitian ini adalah untuk mengetahui perbedaan karakteristik sosiodemografi dari pasien skizofrenia sesuai dengan kondisi pedesaan atau perkotaan tempat tinggalnya. Penelitian observasional dengan rancangan crossectional analitik. Sampel dalam penelitian ini adalah sebanyak 503 orang yang telah didiagnosa skizofrenia dan terdata pada puskesmas se-Kabupaten Badung sampai bulan Oktober tahun 2019. Data sosiodemografi pasien diobservasi kemudian dikelompokan sesuai tempat tinggal pasien pedesaan atau perkotaan. Penelitian ini dianalisis dengan uji Chi-square dengan nilai signifikan P< 0,005. Proporsi kejadian skizofrenia lebih tinggi terjadi pada daerah perkotaan daripada daerah pedesaan (61,1\%:38,9\%), terdapat perbedaan kejadian pada laki-laki dan perempuan di desa dan kota $(p=0,011)$, perbedaan kejadian yang di pedesaan dengan pendidikan rendah sedangkan di perkotaan sebaliknya $(P<0,0001)$, penderita skizofrenia lebih banyak yang tidak bekerja dan tinggal di kota daripada di desa $(p=0,002)$ dan pada status pernikahan penderita yang tidak menikah dan tinggal di kota lebih banyak menderita skizofrenia $(p=0.014)$, hanya variabel kelompok umur tidak terdapat perbedaan $(p=0,14)$. Kejadiaan skizofrenia lebih tinggi terjadi pada daerah perkotaan dengan perbedaan karakteristik ditemukan pada variabel jenis kelamin, tingkat pendidikan, status pekerjaan dan status pernikahan. Hal ini sebagai masukan terhadap dinas kesehatan dan jajaranya agar edukasi psikologis dan screening lebih diarahkan kepada masyarakat perkotaan.

Kata kunci: Skizofrenia, kota, desa, sosiodemografi 


\section{INTRODUCTION}

Schizophrenia is a form of severe mental disorder characterized by fundamental deviations and abnormal characteristics of perceptions, thoughts, feelings or effects, which can experience hallucinations such as listening to voices or seeing things that are not there and disturbances of behaviour and emotions that are not accordingly.

According to $\mathrm{WHO}^{1}$, schizophrenia patients reach more than 21 million people or about 0.2 to $0.4 \%$ of the total population worldwide and are mostly found in those aged 15 to 55 years ${ }^{1}$. The prevalence of schizophrenia in Indonesia is $0.3-1 \%$. If the estimation of the population of Indonesia is around 200 million people, there are about 2 million people suffer from schizophrenia. Data on Riskesdas 2018 showed that Bali Province has the highest prevalence of schizophrenia in Indonesia with a rate of 11 per mile ${ }^{2}$. Based on the annual report of the mental health program known that the prevalence of severe mental disorders in Badung reached 2.5 per mile ${ }^{3}$.

The report of Global Burden Diseases study in 2017 showed that schizophrenia is one of the 20 top diseases causing disability ${ }^{4}$. Disability in schizophrenic patients increases the risk of comorbidities, for instance, diabetes mellitus, coronary heart diseases, stroke, depression, and suicide. The comorbidity decreases life expectancy compared with the general population. The disability condition in schizophrenia patients also results in high family economic burdens, dependency ratios and low quality of life 5 . Globally, the WHO estimates that the cumulative impact of mental disorders spends a cost of US \$ 16,000 billion over 20 years into the future ${ }^{6}$.

The causes of schizophrenia are multifactorial and related to one another. Theories of schizophrenia risk factors are organo -biology (genetics, viruses, malnutrition fetus), psycho-religious, and psychosocial including the psychological, sociodemographic, socio-economic, sociocultural, migration, and population density in a rural and urban area ${ }^{7}$. All these factors are related to one another resulting in a vulnerable psychological condition. Someone who exposed to stressors will more easily become schizophrenia. Aini's study $^{10}$ in Wahyudi \& Febriana ${ }^{8}$ found that the percentage of environmental triggers is the dominant factor, which is $85 \%$ rather than $15 \%$ individual and family factors ${ }^{8}$.

Environmental factor based on place of birth is a dominant factor or schizophrenia trigger factor ${ }^{9}$. The urban community showed significant differences compared to the conditions of rural communities. The urban community are advanced, from the perspective of education and economy. Rural communities are generally described as traditional societies that are slowly developing, while urban communities described as modern societies rapidly develop. The rural-urban difference lies precisely in their discrepancy between the village and the city, both the physical and social territory ${ }^{10}$.

The influence of globalization, modernization, urbanization, and industrialization as the results of science and technology development for improvement in all fields has changed our lifestyle and values. From the perspective of psychiatric, those changes increase the necessities of life, competition on fulfilling those needs, and individualism. Those conditions can trigger psychological stressors resulting in mental changes and require new adjustments ${ }^{11}$.

The prevalence of schizophrenia is associated with the residential area in rural or urban. Urban areas have a higher level of competition, suspense, noise, violence, and feeling threatened than in rural areas. The incidence of schizophrenia among people living in cities with high population density was found two times higher than in rural areas. In a study conducted by $\mathrm{Amin}^{12}$ found that people who live in cities have 3.22 times risk of schizophrenia compared to those who live in rural areas ${ }^{12}$. It is different from the results of Riskesdas in 2013. The results showed that the proportion of severe mental disorders in urban areas was $10.7 \%$ while rural areas were higher $(18.2 \%)$, with a context that poverty in rural areas is higher than in urban areas ${ }^{13}$. 
In a study conducted by Davies in Wahyudi \& Febriana $^{8}$ states that sociodemographic factors on individual, such as marital status, age, employment status, the educational level can affect the risk of suffering from mental disorders. Unmarried, low education level, male, adult age, unemployment may increase the risk of mental disorders ${ }^{8}$.

Research conducted by Alladyce ${ }^{14}$ comparing the onset of schizophrenia on residents who live in urban areas of Camberwell and residents living in rural areas of Dumfries and Galloway. It suggested that the relative risk of schizophrenia for people living in urban areas is 1.61 times compared to those living in the country$\operatorname{side}^{4}$. In a cohort study found an increase of schizophrenia with urban birthplaces 1.34 times compared to the place of birth in the rural area ${ }^{15}$.

Badung regency, one of the regencies in Bali Province, is a tourism area with a high population density. The Badung Regency consists of 6 districts, namely South Kuta, Kuta, North Kuta, Mengwi, Abiansemal and Petang with a total of 62 subdistricts. Thirty-seven sub-districts are urban area, while 25 sub-districts are rural areas. Badung Regency with a high population density will affect the psychological condition of its people ${ }^{16}$.

Based on the description above, the writer is interested in studying the differences in sociodemographic characteristics of urban and rural areas on the number of schizophrenia incidents in Badung Regency.

\section{METHODS}

This research is a quantitative, observational study with a cross-sectional analytic design. The study was conducted in Badung regency using secondary data. A total of 503 samples used in this study were diagnosed schizophrenia from January until October 2019. Univariate analysis conducted to show frequency and distribution of sex, age, education, occupation, and marital status based on patient residential area classified as rural and urban areas. Bivariate analysis conducted to determine differences in socio-demographic characteristics between rural and urban areas, which were then analyzed using the Chi-square test with a significant value of $\mathrm{P}<0.005$.

\section{RESULTS}

The results of data analysis at the health centres in Badung Regency on the research subjects indicated that the proportion of schizophrenia incidence based on the rural and urban was (38.9\%: 61.1\%). Based on the sub-districts, the highest incidence of schizophrenia occurred in the Abiansemal $(38.2 \%)$ and followed by Mengwi $(22.7 \%)$, Petang (13.5\%), North Kuta $(10.9 \%)$, South Kuta $(9.9 \%)$ and Kuta $(4.8 \%)$, relatively. The socio-demographic characteristics on the patients' residential areas showed in the following table. 
Table 1. Socio-demophographical Characteristics of Patients with Schizophrenia in Rural and Urban Areas

\begin{tabular}{|c|c|c|c|c|c|c|}
\hline \multirow{2}{*}{ Variables/Area } & \multicolumn{2}{|c|}{ Rural } & \multicolumn{2}{|c|}{ Urban } & \multicolumn{2}{|c|}{ Total } \\
\hline & $\mathbf{n}$ & $\%$ & $\mathbf{n}$ & $\%$ & $\mathbf{n}$ & $\%$ \\
\hline \multicolumn{7}{|l|}{ Gender } \\
\hline Male & 132 & 67.3 & 172 & 56.0 & 304 & 60.4 \\
\hline Female & 64 & 32.7 & 135 & 44.0 & 199 & 39.6 \\
\hline \multicolumn{7}{|l|}{ Age Group } \\
\hline Youth & 5 & 2.6 & 18 & 5.9 & 23 & 4.6 \\
\hline Adult & 80 & 40.8 & 140 & 45.6 & 220 & 43.7 \\
\hline Ederly & 82 & 41.8 & 120 & 39.1 & 202 & 40.2 \\
\hline Seniors & 29 & 14.8 & 29 & 9.4 & 58 & 11.5 \\
\hline \multicolumn{7}{|l|}{ Education Level } \\
\hline No Education & 14 & 7.1 & 62 & 20.2 & 76 & 15.1 \\
\hline $\begin{array}{l}\text { Did Not Finish Ele- } \\
\text { mentary School }\end{array}$ & 3 & 1.5 & 5 & 1.6 & 8 & 1.6 \\
\hline Primary School & 103 & 52.6 & 63 & 20.5 & 166 & 33.0 \\
\hline Junior High & 43 & 21.9 & 55 & 17.9 & 98 & 19.5 \\
\hline Senior High & 30 & 15.3 & 118 & 38.4 & 148 & 29.4 \\
\hline Bachelor & 3 & 1.5 & 4 & 1.3 & 7 & 1.4 \\
\hline \multicolumn{7}{|l|}{ Profession } \\
\hline Unemployed & 79 & 40.3 & 166 & 54.1 & 245 & 48.7 \\
\hline Housewife & 4 & 2.0 & 8 & 2.6 & 12 & 2.4 \\
\hline Farmer & 76 & 38.8 & 34 & 11.1 & 110 & 21.9 \\
\hline Labor & 10 & 5.1 & 14 & 4.6 & 24 & 48 \\
\hline Traders & 2 & 1.0 & 10 & 3.3 & 12 & 2.4 \\
\hline Private & 16 & 8.2 & 67 & 21.8 & 83 & 16.5 \\
\hline Entrepreneur & 6 & 3.1 & 4 & 1.3 & 10 & 2.0 \\
\hline Civil Servant & 1 & 0.5 & 4 & 1.3 & 5 & 1.0 \\
\hline Retired & 1 & 0.5 & 0 & 0 & 1 & 0.2 \\
\hline $\begin{array}{l}\text { Chief of Traditional } \\
\text { Village }\end{array}$ & 1 & 0.5 & 0 & 0 & 1 & 0.2 \\
\hline \multicolumn{7}{|l|}{ Marital Status } \\
\hline Married & 92 & 46.9 & 105 & 34.2 & 197 & 39.2 \\
\hline Not Married & 96 & 49.0 & 190 & 61.9 & 286 & 56.9 \\
\hline Widow & 8 & 4.1 & 12 & 3.9 & 20 & 4.0 \\
\hline
\end{tabular}


Table 1. shows that most cases of schizophrenia in the Badung regency are male $(60.4 \%)$, adults aged $26-45$ years (43.7\%), elementary school (33.0\%), unemployed $(48.7 \%)$ and unmarried $(56.9 \%)$. Table 1. also shows that cases of schizophrenia in rural areas are mostly men $(67.3$ $\%)$, elderly aged $46-65$ years old $(41.8 \%)$, elementary school (52.6\%), unemployed

Table 2. Differences in Socio-demographic Characteristics among Schizophrenia Patients between Rural and Urban Areas

\begin{tabular}{|c|c|c|c|}
\hline Variables & $\begin{array}{l}\text { Rural } \\
\mathrm{n} /(\%)\end{array}$ & $\begin{array}{l}\text { Urban } \\
\mathrm{n} /(\%)\end{array}$ & P- Value \\
\hline Gender & & & 0,011 \\
\hline Male & $132(67,3)$ & $172(56.0)$ & \\
\hline Female & $64(32,7)$ & $135(44,0)$ & \\
\hline Age Group & & & 0,14 \\
\hline Youth & $5(2,6)$ & $18(5,9)$ & \\
\hline Adult & $80(40,8)$ & $140(45,6)$ & \\
\hline Elderly & $82(41,8)$ & $120(39,1)$ & \\
\hline Seniors & $29(14,8)$ & $29(9,4)$ & \\
\hline Educational Level & & & $<0,001$ \\
\hline Low & $163(83,2)$ & $185(60,3)$ & \\
\hline High & $33(16,8)$ & $122(39,7)$ & \\
\hline Profession Status & & & 0,002 \\
\hline Unemployed & $83(42,3)$ & $174(56,7)$ & \\
\hline Employed & $113(57,7)$ & $133(43,3)$ & \\
\hline Marital Status & & & 0,014 \\
\hline Married & $92(46,9)$ & $105(34,2)$ & \\
\hline Not Married & $96(49,0)$ & $190(61,9)$ & \\
\hline Widow & $8(4,1)$ & $(3,9)$ & \\
\hline
\end{tabular}

$(40,3 \%)$ and unmarried at $49.0 \%$. In the case of schizophrenia in urban areas are predominantly male $(56.0 \%)$, adults aged $26-45$ years $(45.6 \%)$, high school $(38.4 \%)$, unemployed $(54.1 \%)$, and unmarried by $(61.9 \%)$. The correlation between sociodemographic characteristics and patients' residential area showed in Table 2 below. 
Based on chi-square test between patients with schizophrenia who live in the rural and urban areas, it is known that the variables with significant differences are gender $(p$-value $=0.011)$, educational level (p-value $<0.001)$, employment status (pvalue $=0.002)$ and marriage status (pvalue $=0.014)$. Meanwhile, only the age variable ( $\mathrm{p}$ value $=0.14$ ) has no significant difference.

\section{DISCUSSION}

The results indicated that the proportion of schizophrenia incidence based on the rural and urban areas was $38.9 \%$ and $61.1 \%$, respectively. The high incidence of schizophrenia in urban areas is because Badung regency has a lot of urban areas, and close to the Denpasar - the capital of Bali Province. The results are in line with a study by Allardyce ${ }^{14}$ showing that relative risk of schizophrenia in urban areas was $1.61(95 \% \mathrm{CI} ; 1.42$ to 1.82$)$ compared to those in the rural areas ${ }^{14}$. Research by $\mathrm{Chan}^{17}$ revealed that the incidence of schizophrenia among the population in China is higher in urban areas compared to rural areas $(\mathrm{RR}=1.621 .10$ to $2.40)^{17}$. Research by Long $^{18}$ of the study on the prevalence of schizophrenia in mainland China identified from the electronic database until July 2013 also found that the incidence is higher in urban residents than rural ${ }^{18}$.

The highest incidence of schizophrenia occurred in the Abiansemal sub-district $(38.2 \%)$ as Abiansemal was the only subdistrict that has a mental health unit at Abiansemal Primary Health Center 1.

There are differences in the number of schizophrenia occurrences in rural and urban areas, where the sample of schizophrenia patients in men has a higher number than women. Besides, the majority of schizophrenic male patients live in urban areas. The condition caused by men living in urban areas has higher stress levels. The men have a responsibility as the breadwinner and must deal with economic competition so that the pressure in life tends to be high$\mathrm{er}^{19}$. The results of research by Sukanta ${ }^{20}$ also showed that the incidence of schizophrenia is more prevalent in urban and male ${ }^{20}$. A study of schizophrenia incidence in mainland China from 1965 to 2001 conducted by $\mathrm{McGrath}^{21}$ also found a significantly higher incidence of schizophrenia occur in men who live the urban areas rather than those at rural $\operatorname{areas}^{21-23}$.

This study showed differences in educational level between the schizophrenia patients in urban and rural areas. Schizophrenia patients who live in urban areas have a higher level of education than rural areas as the government's is more likely to pay attention to the quality of education in urban areas, so the quality of education in urban areas is better dan in the rural areas. Besides, the socio-economic level in urban areas is better than in rural areas. It causes urban people to be more enthusiastic for a higher education level. However, the increasingly crowded urban areas have increased competition for life to fulfil the necessities, which has led to an increase of life pressure among people in urban ar$\mathrm{eas}^{24}$. Another factor caused by the large number of patients forced to discontinue school because they have schizophrenia. It affects the patient's social life. The low level of education becomes one of the obstacles in social interaction and in getting information about schizophrenia. The results are in line with a study conducted by Yanuar $^{25}$ which found that the majority of people with mental disorders are poorly educated $(73 \%)$ but showed no significant relationship $(p=0.941)$. Similarly, a study by Erlina \& Pramono ${ }^{26}$ showed that the majority of schizophrenia patients have a low educational level but had no significant different $(p>0.05)^{25}$.

Profession among the schizophrenia patients showed a significant difference between schizophrenic patients who are unemployed and those who work in rural and urban areas. Rural areas offer more opportunities for people with schizophrenia to use their capacities for productive work. For instance, available jobs in the rural area (such as farmer) may be more accessible for people with schizophrenia than the available jobs in urban areas such as labour 
in manufacturing. Work is important and beneficial for people with schizophrenia to be able to participate and socialize in society. Overall, schizophrenia patients in Badung Regency are often unemployed. The results of this study are in line with research conducted by Erlina \& Pramono ${ }^{26}$ showed that more schizophrenic patients are unemployed and there is a significant difference of the incidence of schizophrenia -related to the profession ${ }^{26}$. Rosemarie ${ }^{27}$ also stated a relationship between the job status and the onset of schizophrenia ${ }^{27}$. Unemployed individuals are more easily stressed causing helplessness, while people who work have a sense of optimism about the future and have greater motivation for life than those who are unemployed ${ }^{28}$.

Marital status showed a significant difference in schizophrenia patients who unmarried between those who live in rural and urban areas. Unmarried patients with schizophrenia are higher in urban areas than in rural areas. Many child marriages occur because of poverty, difficult geographical location, low educational access, and unclearly regulated policies. Girls from rural areas are susceptible more of getting married than from urban areas as they most likely come from low-income families, and lack of education or drop out of school ${ }^{11}$. The results from a study by Fakhari ${ }^{29}$ showed that unmarried individuals have a risk of getting schizophrenic than the general population. A married individual can exchange egos and identify behaviours between husband and wife to achieve peace $^{29}$. Besides that, attention and affection are the basis for achieving a better social life. Moreover, a study by Koujalgi $\&$ Patil $^{22}$ found a significant difference in the variables of marital status. The study also showed that the ratio of people who are unmarried among schizophrenia patients is $57 \%$ because of their unstable personality condition that becomes a barrier for them to marry ${ }^{22}$.

The age groups variable showed no significant difference between rural and urban areas. In urban areas, most schizophrenia patients are the adult (26-45 years old, the average age of 46 years), while in rural areas most of the patients are an elderly group (46-65 years old, the average age of 50 years). In general, most patients with schizophrenia are an adult with age between 26-45 years old. The result is in line with a study by Handayani ${ }^{30}$ conducted on schizophrenic patients who hospitalized at the Grhasia Mental Hospital, DIY. The study showed that the majority of the patients with schizophrenia are aged 25-44 years old $(55.7 \%)$. No statistically difference is found among age groups and area of residency $(p=0.14)^{30}$. Symptoms of schizophrenia usually appear in late adolescence or young adulthood. The onset in men is generally between $15-25$ years and in women between 25-35 years ${ }^{28}$. Age 25-35 years old are likely to have a 1.8 times greater risk of suffering from schizophrenia than those aged 17-24 years $^{26}$.

\section{CONCLUSION}

Characteristics of schizophrenia patients who live in the rural areas are unmarried men aged 46-65 years old, only have elementary education level and unemployed. Meanwhile, the characteristics of schizophrenia patients living in urban areas are mostly unmarried adult men (26-45 years old), only have high school educational level and unemployed. Based on the different test among the characteristic variables between rural and urban schizophrenia patients, the significant variables are gender, education level, profession status and marital. Meanwhile, the age group variable shows no significant difference between schizophrenia patients living in rural and urban areas.

Based on the results, we recommended to the government to do mental health screening and community training for people who live in urban areas to prevent the emergence of stressors that cause schizophrenia disorder. Besides, people with schizophrenia should be included in groups of peer house that provides treatment, guidance, and skills so that they can be independent and have a meaningful life. 


\section{REFERENCES}

1. Word Health Organization (WHO) . (2019). Schizophrenia, Word Health Organization.

2. Kementerian Kesehatan (2018). Hasil Utama Riskesdas.

3. Dinas Kesehatan Kabupaten Badung. (2018). Laporan Tahunan Seksi Pencegahan dan Penanggulangan Penyakit Tidak Menular dan Kesehatan Jiwa.

4. Metrics, G. H. (2018). Global, regional, and National DisabilityAdjusted Life-Years (DALYs) for 359 Diseases and Injuries and Healthy Life Expectancy (HALE) for 195 Countries and Territories, 1990 2017 : A Systematic Analysis for The Global Burden of Disease Study 2017, p. 1990-2017. doi: 10.1016/ S0140-6736(18)32335-3.

5. Swain, S. P., Behura, S. S., Centre, N. C. \& Consultation, N. (2016). A Comparative Study of Quality of Life and Disability Among Schizophrenia and Obsessive-Compulsive Disorder Patients in Remission. Industrial Psychiatry of India, 25(2), p. 210215. doi: 10.4103/ipj.ipj.

6. World Health Organization. (2011). Global Burden of Mental Disorders and The Need for A Comprehensive, Coordinated Response from Health and Social Sectors at the Country Level Report by The Secretariat.

7. Hawari, D. (2012). Skizofrenia Edisi Ketiga Pendekatan Holistik (BPSS) Bio-Psiko Sosial Spiritual. Badan Penerbit Fakultas Kedokteran UI, Jakarta.

8. Wahyudi, A. \& Febriana, A. I. (2016). Faktor Risiko Terjadinya Skizofrenia (Studi Kasus di WilayahKerja Puskesmas Pati II), Public Health Perspective, 1(1), p. 112.

9. Hermiati, D. \& Harahap, R. M. (2018). Faktor Yang Berhubungan Dengan Kasus Skizofrenia Pada Pasien Rawat Inap Rumah Sakit Khusus Jiwa Soeprapto Provinsi
Bengkulu. 1(2), p. 78-92.

10. Suparmini \& Wijayanti, A. T. (2015). Buku Ajar Masyarakat Desa dan Kota (Tinjauan Geografis, Sosiologis dan Historis).

11. Richardson, L., Hameed, Y., Perez, J., Jones, P. B. \& Kirkbride, J. B. (2018). Association of Environment With the Risk of Developing Psychotic Disorders in Rural Populations Findings from the Social Epidemiology of Psychoses in East Anglia Study. 75(1), p. 75-83. doi: 10.1001/jamapsychiatry.2017.3582.

12. Amin, M. (2009). Peran Daerah Tempat Tinggal Terhadap Kejadian Penyakit Skizofrenia Pada Penderita Gangguan Jiwa Yang DiRawat Inap Di Rumah Sakit dr. Ernaldi Bahar Provinsi Sumatera Selatan. Universitas Indonesia.

13. Kementerian Kesehatan. (2013). Riset Kesehatan Dasar. Available at: http://www.depkes.go.id/resources/ download/general/Hasil Riskesdas 2013.

14. Allardyce, J., Boydell, J., Os, J. V., Morrison, G., Castle, D., et al. (2001). Comparison of The Incidence of Schizophrenia in Rural Dumfries and Galloway and Urban Camberwell. Britsh Journal Of Psychiatry, p. 335-340.

15. Harrison, G., Fouskakis, D., Rasmussen, F., Tynelius, P. \& Gunnell, D. (2003). Association Between Psychotic Disorder and Urban Place of Birth is Not Mediated by Obstetric Complications or Childhood Socio-Economic Position: a Cohort Study. University Press Cambridge, (1998), p. 723-731.

16. Badan Pusat Statistik Kabupaten Badung 2018. Badung Dalam Angka Kabupaten Badung.

17. Chan, K., Yee, T., Zhao, Fei, Meng, Shijiao, et al. (2015). Prevalence of schizophrenia in China between 1990 and 2010, 5(1), p. 1-8. doi: 10.7189/ jogh.05. 010410 .

18. Long, J., Huang, G., Liang, W., Liang, B., Chen, Q., Xie, J., et al. 
(2014). The Prevalence of Schizophrenia in Mainland China: Evidence from Epidemiological Surveys. p.244-256. doi: 10.1111/ acps. 12296.

19. Zahnia, S. \& Sumekar, W. D. (2013). Kajian Epidemiologis Skizofrenia Epidemiologic Study of Schizophrenia. Fakultas Kedokteran, Universitas Lampung

20. Sukanta, S., David, C., Welham, J. \& Mcgrath, J. (2005). A Systematic Review of the Prevalence of Schizophrenia, Plos Medicine, 2(5). doi: 10.1371/journal.pmed.0020141.

21. Mcgrath, J., Saha, S., Welham, J., Saadi, O. El, Maccauley, C. \& Chant, D. (2004). A systematic Review of The Incidence of Schizophrenia: The Distribution of Rates and The Influence of Sex, Urbanicity, Migrant Status and Methodology. 22, p. 1-22.

22. Koujalgi, S. R. \& Patil, S. R. (2013). Comparison of Demographic Profile of Patient with Schizophrenia and Depression. 40(1). doi: 10.4103/0974 -5009.109686.

23. Thorup, A., Waltoft, B. L., Pedersen, C. B., Mortensen, P. B. \& Nordentoft, M. (2007). Young Males Have A Higher Risk of Developing Schizophrenia: A Danish Register Study. Cambridge University Press, (February), p. 479-484. doi: 10.1017/ S0033291707009944.

24. Wahyudi, A., Apsari, N. C. \& Padjadjaran, U. (2015). Desa dan kota dalam Potret Pendidikan. Reserchgate, 2(June 2020), p. 301444. doi: 10.24198/jppm.v2i3.13592.
25. Yanuar, Rio. (2011). Analysis Of Factors Related To Mental Disorder Incidents At Paringan Village. Fakultas Keperawatan Universitas Airlangga.

26. Erlina, S. \& Pramono, D. (2010). Determinan Terhadap Timbulnya Skizofrenia Pada Pasien Rawat Jalan Di Rumah Sakit Jiwa Prof. HB Saanin Padang Sumatera Barat. 26 (2), p. 71-80.

27. Rosemarie, M., Julian, L., Dinesh, B., Pang, D. \& Zhao, J. H. (2002). Social Environment, Ethnicity and Schizophrenia. Soc Psychiatry Psychiatr Epidemiol, p. 329-335. doi: 10.1007/s00127-002-0557-4.

28. Zahnia, Siti \& Sumekar, Dyah Wulan. (2013). Kajian Epidemiologi Skizofrenia. Bagian Ilmu Kedokteran Komunitas dan Ilmu Kesehatan Masyarakat Fakultas Kedokteran Universitas Lampung.

29. Fakhari, A., Ranjbar, F., Dadashzadeh, H. \& Moghaddas, F. (2007). An Epidemiological survey of Mental disorders Among Adults in The North, West Area of Tabriz, Iran, 23(1).

30. Handayani, L., Febriani, Rahmadani, A., Saufi, A., Masyarakat, F. K., Dahlan, U. A., et al. (2015). Faktor Risiko Kejadian Skizofrenia di Rumah Sakit Jiwa Grahasia Daerah Istimewa Yogyakarta (DIY). Fakultas Kesehatan Dahlan, Universitas Ahmad Soepomo, Jalan Prof Yogyakarta. 13(2), p. 135-148. 